Article

\title{
Reclamation of Saline-Sodic Soils with Combined Amendments: Impact on Quinoa Performance and Biological Soil Quality
}

\author{
María Alcívar ${ }^{1}$, Andrés Zurita-Silva ${ }^{2}$ (D), Marco Sandoval ${ }^{1}$, Cristina Muñoz ${ }^{1}$ \\ and Mauricio Schoebitz ${ }^{1, *(1)}$ \\ 1 Department of Soils and Natural Resources, Faculty of Agronomy, Universidad de Concepción, \\ Campus Chillan, Avenida Vicente Méndez 595, Chillán, Chile; maryfer2323@hotmail.com (M.A.); \\ masandov@udec.cl (M.S.); cristinamunoz@udec.cl (C.M.) \\ 2 Instituto de Investigaciones Agropecuarias, (INIA), Centro de Investigación Intihuasi, \\ Colina San Joaquin s/n, La Serena, Coquimbo, Chile; andres.zurita@inia.cl \\ * Correspondence: mschoebitz@udec.cl; Tel.: +56-41-2661438
}

Received: 17 July 2018; Accepted: 14 August 2018; Published: 30 August 2018

check for updates

\begin{abstract}
The objective of this study was to evaluate the individual and synergic effects of the application of Biochar (B), Humic Substances (HS), and Gypsum (G) on the soil properties of a saline-sodic soil, and plant growth and seed quality (polyphenols, protein and yield) of quinoa. Treatments included (B) $22 \mathrm{t} \mathrm{ha}^{-1}$, (HS) $5 \mathrm{~kg} \mathrm{ha}^{-1}$, and (G) $47.7 \mathrm{t} \mathrm{ha}^{-1}$. Two quinoa genotypes from Arid Zones (AZ-51 and AZ-103) were selected and established in eight treatments. The B + HS + G combined treatment resulted in increases in root biomass of $206 \%$ and $176 \%$ in AZ-51 and AZ-103, respectively. Furthermore, electrical conductivity (ECe), sodium adsorption ratio (SAR), and exchangeable sodium percentage (ESP) decreased significantly in all treated soils. When compared to the control, ESP decreased 11-fold in the G treatment, and 9-13-fold in the B + G; B + HS; and B + HS + G treatments. Similarly, soil microbial biomass increased $112 \%$ and $322 \%$ in the B + HS + G treatment in AZ-51 and AZ-103 genotypes, respectively. Therefore, it can be concluded that the application of combined amendments $(B+H S+G)$ represents an alternative for reclaiming degraded soils, including saline-sodic soils.
\end{abstract}

Keywords: biochar; humic substances; salinity; sodicity; ESP; microbial biomass

\section{Introduction}

Soil degradation resulting from salinity and sodicity is a major environmental threat to soil fertility and agricultural productivity in arid and semiarid regions of the world [1]. Saline-sodic soils are degraded due to the simultaneous effect of salinity and sodicity. This causes loss of soil physical structure by clay swelling, and dispersion because of high $\mathrm{Na}^{+}$concentrations in the soil solution or at the exchange phase [2]. Apart from these physicochemical effects, this leads to biological properties, such as microbial respiration and biomass, becoming worse [3]. On the other hand, salinity affects plant growth by creating osmotic imbalances and specific ion toxicities [4], which pose limitations to morphological, histological, chemical, biochemical, and metabolic processes. In turn, these reduce stomatal opening and photosynthetic rate, leading to decreased plant growth, crop yield, and quality [4,5]. Agricultural adaptation to changing climatic conditions, expected to entail increasing soil salinization, relies on the use of crops that can tolerance abiotic and biotic stresses [6]. In this sense, quinoa (Chenopodium quinoa Willd.) has been considered for agricultural diversification due to its extraordinary adaptability to various environmental stresses, such as soil 
salinity, low temperature, drought, and nutrient-poor soils [7]. In the last decades, quinoa has attracted the attention of researchers and consumers worldwide for being one of food plants with the highest content of essential aminoacids, vitamins, phenolic compounds, and minerals [8]. However, high salinity can negatively influence root length, chlorophyll content, plant growth, as well as seed yield [6,9]. According to Ramzani et al. [10], salt-affected soils influence the nutritional quality of quinoa seeds so that protein content decreases, whereas polyphenol levels increase. Therefore, a successful reclamation of saline-sodic soils is of great importance for crop productivity [11], and a key factor in addressing the world's food security challenges [12]. Reclamation of saline-sodic soils requires the removal of sodium from the soil exchange sites by divalent cations (preferably $\mathrm{Ca}^{2+}$ ) to promote soil flocculation. The most common amendment source can be calcium, which provides soluble calcium within the soil. The replaced $\mathrm{Na}^{+}$is removed either below root zone or out of the soil profile by leaching water [13]. Gypsum is the most commonly applied product for the reclamation of saline-sodic soils and can improve physical and chemical soil properties primarily by maintaining a favorable electrolyte concentration in soil solution. As adsorbed $\mathrm{Na}^{+}$on exchangeable sites of clay particles are considered to be responsible for soil dispersion, gypsum can prevent it by maintaining high $\mathrm{Ca} / \mathrm{Na}$ ratios, and thus promoting clay flocculation and structure stability [14]. On the other hand, organic amendments can increase dissolution of native calcite $\left(\mathrm{CaCO}_{3}\right)$ minerals via increased formation of carbonic acid in the soil profile, thus dissolution could release $\mathrm{Ca}^{2+}$ in the soil solution to facilitate the removal of $\mathrm{Na}^{+}$from cation exchange sites [15]. Therefore, the addition of organic matter also represents an alternative for reclaiming a variety of degraded soils, including salt-affected soils. In fact, significant improvements have been reported regarding soil physical, chemical, and biological characteristics with the use of organic matter [16]. Gupta et al. Ref. [17] found that the combined application of gypsum and organic amendments in sodic soils improved soil properties, resulting in decreased soil bulk density, electrical conductivity (EC), and exchangeable sodium percentage (ESP), but also in increased soil biological activity. Humic substances are widely recognized as key components of soil fertility because they control the physicochemical and biological properties of the rhizosphere, perform various functions in the soil and regulate plant growth. In fact, humic substances improve soil properties, such as aggregation, aeration, and water holding capacity [18,19]. Furthermore, Ciarkowska et al. [20] reported that humic substances applied to the soil contributed substantially to improve soil quality status, resulting in increased organic carbon, enzymatic activity, root biomass, and yield. Biochar is another soil amendment [21] that can improve soil physical conditions. It is more recalcitrant than humic substances and less likely to directly support microbial growth, but it can significantly promote soil biological activity due to the release of temporary labile pyrolysis products [22]; however, this effect could be very temporary [23]. Salt-affected soils can benefit from biochar application by increased contents of soil organic carbon and nutrients $\left(\mathrm{K}^{+}, \mathrm{Ca}^{2+}, \mathrm{Mg}^{2+}, \mathrm{Zn}, \mathrm{Mn}\right)$, increased surface area, enhanced physical properties by balancing water content and air porosity, increased retention of polyvalent cations, and replacement of $\mathrm{Na}^{+}$from exchange sites by providing $\mathrm{Ca}^{2+}$ in soil solution [24]. In this sense, the addition of organic amendments in combination with gypsum has proven successful in reducing adverse effects on soil properties associated with a high content of sodium. However, there is no information about the synergistic effects between biochar, humic substances, and gypsum on the reclamation of saline-sodic soils and their impact on quinoa crop growth. The objectives of this study were: (a) to evaluate changes in the chemical and biological characteristics of saline-sodic soil after the application of combined amendments B, HS, G; (b) to evaluate the effects of these amendments on the physiology, productivity, and seed quality of two quinoa genotypes. The hypothesis tested in this work was that the combined application of amendments enhances chemical and biological properties of saline-sodic soils, and that this effect on soil properties could in turn result on a significant impact on quinoa performance. 


\section{Materials and Methods}

\subsection{Experimental Site}

The experiment was conducted in pots $(21 \mathrm{~cm}$ diameter, $30 \mathrm{~cm}$ height $)$ filled with $1 \mathrm{~kg}$ of saline-sodic soil. All plants were grown under controlled greenhouse conditions (temperature between $20 \pm 2{ }^{\circ} \mathrm{C}$; day length $12 \mathrm{~h}$; average humidity 65\%) at the Soil Biology Laboratory of the Faculty of Agronomy, University of Concepción, Biobío Region, Chile. The lighting system consisted of three lamps of $300 \mathrm{~W}$. Light intensity was $350 \mu \mathrm{mol} \mathrm{m} \mathrm{m}^{-2} \mathrm{~s}^{-1}$.

\subsection{Soil Sampling}

Saline-sodic soil samples were collected at $20 \mathrm{~cm}$ depth from Huasco county $\left(28^{\circ} 28^{\prime} \mathrm{S} ; 71^{\circ} 10^{\prime} \mathrm{W}\right)$, Atacama Region, Chile. Bulk soils were air-dried and crushed to pass through a $2 \mathrm{~mm}$ sieve and were homogenized by thorough mixing. According to soil taxonomy [25], the soil under study was classified as a Typic Aquic Torriorthents, equivalent to an Endosalic Sodic Regosols (Ochric Aridic) soil type in WRB classification. It corresponds to a silty franc soil with a bulk density of $1.10 \mathrm{~g} \mathrm{~cm}^{-3}$; ECe of $218.5 \mathrm{dS} \mathrm{m}^{-1}$ saturation paste; a $\mathrm{pH}$ of 7.6; a sodium adsorption ratio (SAR) of $96.3 \%$; a cation exchangeable capacity (CEC) of $189.4 \mathrm{cmol} \mathrm{kg}^{-1}$ soil; an organic matter content of $2.96 \%$; P-Olsen value of $40.2 \mathrm{mg} \mathrm{kg}^{-1}$; and available $\mathrm{K}$ of $734.8 \mathrm{mg} \mathrm{kg}^{-1}$. The climate at the collection site is arid, with an average temperature of $15^{\circ} \mathrm{C}$, average relative humidity of $70.2 \%$, and annual precipitation of $40 \mathrm{~mm}$ [26].

\subsection{Germination Assay}

A germination test was conducted in order to assess the germinability of quinoa seeds grown under natural conditions of soil salinity. Plastic pots of $2160 \mathrm{~mL}$ capacity with drainage holes were filled with $1000 \mathrm{~g}$ of the sampled soil. Twenty quinoa seeds were sown in each pot and evaluated in 64 experimental units; each treatment was replicated four times. Germination (\%) was evaluated 10 days after sowing (DAS) [6]. This allowed measuring seed germination inhibition as a result of salt toxicity and soil cracking (germination average reached 6.7\%; data not shown). However, all plants died few days after emergence. For this reason, a volume of $200 \mathrm{~g}$ of vermiculite was added to each pot and mixed with the soil thoroughly to reduce soil cracking. Subsequently, soil leaching occurred.

\subsection{Leaching}

Leaching was applied before seedlings were planted to decrease the high salinity of the soil. It consisted in partially adding tap water for thirty days, applying 151 pot $^{-1}$. The soil electrical conductivity post leaching was $15 \mathrm{dS} \mathrm{m}^{-1}$. Soil leaching is an agricultural practice commonly used in Huasco in order to reduce soil salinity to levels that crop to be grown can tolerate. The average ECe value for Huasco soils is $17 \mathrm{dS} \mathrm{m}^{-1}$ [27].

\subsection{Amendments}

Pine-woodchip biochar and humic substances were used as organic amendments, while gypsum was used as an inorganic amendment. Biochar was produced by slow pyrolysis at $450^{\circ} \mathrm{C}$ for $30 \mathrm{~min}$ and then cool to room temperature for $60 \mathrm{~min}$. Processing of carbonaceous material was carried at the UDT (Technology Unit of the University of Concepción - Chile). Some properties of biochar are presented below: total carbon (C \%) 46; total nitrogen ( $\mathrm{N} \%$ ) 0.5; C:N ratio 98.5; total Ca $-\mathrm{Mg}(\%)$ : $0.8-0.12$ [28]. Biosolve (Oiko, Chile) product containing $70 \%$ humic acids, $15 \%$ fulvic acids, and $10 \%$ $\mathrm{K}_{2} \mathrm{O}$ was used as source of humic substances derived from leonardite. Gypsum was obtained from the local market, with a composition of $\mathrm{SO}_{4} 16-18 \%, \mathrm{CaO} 23-24 \%$.

The gypsum requirement of the soil was determined using the following equation [29]:

$$
\mathrm{GR}=(\mathrm{ESPi}-\mathrm{ESPf}) \times \mathrm{CEC} \times \mathrm{BD} \times \mathrm{SD} \times \mathrm{F} 0.00086
$$


where GR is the net gypsum requirement of the soil $\left(\mathrm{t} \mathrm{ha}^{-1}\right)$; ESPi is the initial exchangeable sodium percentage; ESPf is the final exchangeable sodium percentage; CEC is the cation exchangeable capacity $\left(\mathrm{cmol} \mathrm{kg}^{-1}\right)$; $\mathrm{SD}$ is the soil depth $(\mathrm{cm})$; BD is bulk density $\left(\mathrm{g} \mathrm{cm}^{-3}\right)$; and $\mathrm{F}$ is the Ca-Na exchange efficiency.

To reduce initial soil ESP from $58 \%$ to $45 \%, 47.7 \mathrm{t} \mathrm{ha}^{-1}$ of GR was used.

\subsection{Experimental Procedure}

AZ-103 and AZ-51 quinoa genotypes from Arid Zones (AZ) were obtained as dry seed batch from the Quinoa Breeding Program at INIA (National Institute for National research) Intihuasi (Chile). Both of them correspond to coastal/lowlands ecotypes characterized by early and intermediate maturity: 150-170 days after sowing (DAS), respectively.

At two-leaf stage, two plants per pot were transplanted. An amount of $160 \mathrm{~kg} \mathrm{ha}^{-1}$ was applied at rates of $30 \%$ and $70 \%$ at sowing and branching stages, respectively. Neither $\mathrm{P}_{2} \mathrm{O}_{5}$ nor $\mathrm{K}_{2} \mathrm{O}$ were applied because the results of soil analysis showed that the initial soil condition could provide sufficient amounts of nutrients for the proper development of the crop.

Plants were allowed to grow to harvest maturity so that AZ-103 and AZ-51 genotypes were harvested 112 and 137 DAS, respectively. Biochar, humic substances, and gypsum were applied at rates of $22 \mathrm{t} \mathrm{ha}^{-1}(1 \% \mathrm{w} / \mathrm{w})$ [30]; $5 \mathrm{~kg} \mathrm{ha}^{-1}$ [31]; and $47.7 \mathrm{t} \mathrm{ha}^{-1}$, respectively. For each experimental unit of $1 \mathrm{~kg}$ soil, the following treatments were applied: $\mathrm{T} 1=\mathrm{B}\left(10 \mathrm{~g} \mathrm{pot}^{-1}\right) ; \mathrm{T} 2=\mathrm{G}\left(22 \mathrm{~g} \mathrm{pot}^{-1}\right)$; $\mathrm{T} 3=\mathrm{HS}\left(2.3 \mathrm{mg} \mathrm{pot}^{-1}\right) ; \mathrm{T} 4=\mathrm{B}+\mathrm{G}\left(10+22 \mathrm{~g} \mathrm{pot}^{-1}\right) ; \mathrm{T} 5=\mathrm{B}+\mathrm{HS}\left(10 \mathrm{~g}+2.3 \mathrm{mg} \mathrm{pot}^{-1}\right) ; \mathrm{T} 6=\mathrm{HS}+\mathrm{G}$ $\left(2.3 \mathrm{mg}+22 \mathrm{~g} \mathrm{pot}^{-1}\right) ; \mathrm{T} 7=\mathrm{B}+\mathrm{HS}+\mathrm{G}\left(10 \mathrm{~g}+2.3 \mathrm{mg}+22 \mathrm{~g} \mathrm{pot}^{-1}\right) ; \mathrm{T} 0=$ Control (unamended soil). Eight treatments were evaluated for two quinoa genotypes; plants were watered at field capacity $(100 \%)$. Soil moisture was monitored by means of sensors (MORPHO, GS-1), and readings were recorded in a data logger (DECAGON-EM50 Series). Four replicates of each genotype were considered, and two plants per treatment were evaluated in 64 experimental units.

\subsection{Plant Parameters Studied}

Shoot and root dry weights were measured by oven-drying at $65^{\circ} \mathrm{C}$ for 24 hours. Measurements were made using an analytical balance. Root length was estimated using WinRhizo ${ }^{\circledR}$ Root Analysis System software (Régent Instrument Inc., Canada). The plant physiological variables evaluated were stomatal conductance and chlorophyll index. Stomatal conductance was determined during anthesis using a Porometer (DECAGON DEVICES model SC-1, USA), while chlorophyll index (soil plant analysis development (SPAD) values) was determined by a portable meter 502 (Minolta Spectrum Technologics Inc., Plainfield, IL, USA). Measurements were made on fully expanded leaves from the upper part of the foliage.

\subsection{Seed Parameters Measured}

Seed yield ( $\mathrm{g} \mathrm{plant}^{-1}$ ): plant seeds of each plot were weighed on an analytical balance. Protein content (\%) in seeds was determined by analyzing nitrogen content according to the Kjeldahl method. Then, the factor conversion of nitrogen to pure protein was used (5.73).

Polyphenols in seed were determined using the Folin Ciocalteu Reagent method [32]. Sample extracts $(0.025 \mathrm{ml})$ were added to $0.12 \mathrm{~mL}$ Folin Ciocalteau Reagent $1 \mathrm{~N}$ and $1.6 \mathrm{~mL} \mathrm{H}_{2} \mathrm{O}$. After $3 \mathrm{~min}$, $0.3 \mathrm{~mL}$ of $20 \% \mathrm{Na}_{2} \mathrm{CO}_{3}$ were also added. The mixture was incubated at room temperature for $2 \mathrm{~h}$, and absorbance was measured at $760 \mathrm{~nm}$ against the blank sample. Total polyphenol content was expressed as Gallic Acid Equivalents (GAE) in $\mathrm{mg} \mathrm{g}^{-1}$.

\subsection{Chemical and Biological Soil Analysis, and Leaf Tissue Analysis}

Chemical analyses were performed measuring $\mathrm{pH}, \mathrm{ECe}$, and soluble cations $\left(\mathrm{Ca}^{2+}, \mathrm{Mg}^{2+}, \mathrm{Na}^{+}\right)$of saturation paste following standard methods [33]. In addition, exchangeable cation concentrations 
were measured [33]. All analyses were conducted in the ISO 17025 accredited laboratories of the Department of Soils and Natural Resources of the University of Concepción.

ESP was calculated by the following equation where the concentrations of exchangeable cations are expressed in $\mathrm{cmol} \mathrm{kg}^{-1}$ :

$$
\mathrm{ESP}=\mathrm{Na}^{+} /\left(\mathrm{Na}^{+}+\mathrm{K}^{+}+\mathrm{Ca}^{2+}+\mathrm{Mg}^{2+}\right) \times 100 \%
$$

SAR was calculated by the following equation where a chemical element symbol indicates a concentration in meq $1^{-1}$ :

$$
S A R=\frac{N a^{+}}{\sqrt{\left(C a^{+2}+M g^{+2}\right) / 2}}
$$

Microbial soil biomass activity was determined by hydrolysis of fluorescein diacetate (FDA). For this analysis, an amount of $0.5 \mathrm{~g}$ of wet soil was weighed in screw cap test tubes; samples were in triplicate and a blank was also included. Amounts of $4.95 \mathrm{~mL}$ of sodium phosphate buffer and $0.05 \mathrm{~mL}$ of FDA were added and stirred, and then tubes were placed in a thermoregulated bath at $25^{\circ} \mathrm{C}$ for $1 \mathrm{~h}$. Subsequently, samples were cooled in an ice bath, and a volume of $5 \mathrm{~mL}$ of acetone was added. The solutions were shaken and filtered, and absorbance was read at $490 \mathrm{~nm}$ in a spectrophotometer against a reagent blank [34]. Soil respiration was determined by weighing $20 \mathrm{~g}$ of soil (in duplicate) per treatment, and placed in an incubation bottle. A volume of $7.5 \mathrm{~mL}$ of $\mathrm{NaOH}$ was added in a centrifuge tube and placed in an incubation bottle. Then, bottles without soil (blank) were hermetically closed and remained in an incubation chamber at $22{ }^{\circ} \mathrm{C}$ and constant humidity for 7 days. After the incubation time, a volume of $1 \mathrm{~mL}$ of $\mathrm{NaOH}$ was taken from the centrifuge tube and mixed with a volume of $2 \mathrm{~mL}$ of $\mathrm{BaCl}_{2}$, and then the solution was titrated with $\mathrm{HCl} 0.1 \mathrm{M}$. The data were expressed as $\mu \mathrm{g} \mathrm{CO} 2-\mathrm{C} \mathrm{g}^{-1}$ soil oven dried $\left(105^{\circ} \mathrm{C}\right)$ [34].

Sodium leaf analyses were performed following standard methods [35].

\subsection{Statistical Analysis}

The study was conducted using a completely randomized design consisting of 2 factors $(2 \times 8)$. The first factor corresponded to quinoa genotypes (AZ-51 and AZ-103), while the second corresponded to three different amendments: biochar, humic substances, and gypsum (applied alone or combined). The data were analyzed using one-way ANOVA; the normality was verified using the modified Shapiro-Wilks test, and the mean separation was performed by the Duncan test $(p<0.05)$. SAR, ESP, $\mathrm{Na}+$ values were transformed with the expression $(x+0.5)^{0.5}$ prior to entering data to the statistical software InfoStat version 2016e.

\section{Results}

\subsection{Effects of the Amendments on Growth and Physiological Parameters of Quinoa Plants}

One of the objectives of this research was to evaluate the effects of the application of biochar, humic substances, and gypsum on quinoa growth. The root biomass in AZ-51 quinoa genotype showed a significant increase of $413 \%$ in the B + HS + G treatment when compared to the control. The combined applications of B + G; B + HS; and B + HS + G also resulted in significant increases of 57, 73, and 93\% in the root biomass of AZ-103 genotype, respectively (Table 1). In terms of root length, HS + G; B; $\mathrm{B}+\mathrm{HS}+\mathrm{G}$ resulted in significant increases of 51,76, and 106\%, respectively, in AZ-51 compared to the control treatment, while AZ-103 also exhibited significant increases in B; B + G; and B + HS treatments respect to the control (Table 1).

Regarding physiological variables of quinoa, chlorophyll index (SPAD values) in AZ-51 genotype did not increase significantly with amendment applications when compared to the control ( $p$ value $=0.1028)$. Despite this, the same parameter showed significant increases in AZ-103 for all treatments compared to the control. The highest SPAD values were obtained with $\mathrm{HS}+\mathrm{G} ; \mathrm{G} ; \mathrm{B} ; \mathrm{B}+\mathrm{G}$; 
and B + HS, with increases of $39,33,32,30$, and 27\%, respectively, compared to the control (Table 2). On the other hand, amendment applications resulted in significant increases in stomatal conductance in both quinoa genotypes. When compared to the control treatment, this parameter was significantly higher in AZ-51 for B + HS + G; HS; B + G; G; and B + HS treatments, whereas all treatments were significant higher in AZ-103 genotype (Table 2).

Seed yield in AZ-51 genotype presented significant increases of 116 and $85 \%$ for G and HS + G treatments, respectively (Duncan test $p>0.05$ ), while a similar behavior was observed in all treated soils in AZ-103 compared to the control (Figure 1).

Table 1. Influence of chemical and organic amendments on root length and root dry weight of quinoa genotypes grown in saline-sodic soil.

\begin{tabular}{lllll}
\hline \multirow{2}{*}{ Treatments } & \multicolumn{2}{l}{ Root Dry Weight (g plant $^{-1}$ ) } & \multicolumn{2}{l}{ Root Length (cm) } \\
\cline { 2 - 5 } & AZ-51 & AZ-103 & AZ-51 & AZ-103 \\
\hline C & $0.48 \pm 0.06 \mathrm{~b}$ & $1.13 \pm 0.12 \mathrm{c}$ & $415 \pm 79.2 \mathrm{~cd}$ & $329 \pm 41.8 \mathrm{~d}$ \\
$\mathrm{~B}$ & $0.83 \pm 0.23 \mathrm{~b}$ & $1.49 \pm 0.06 \mathrm{bc}$ & $729 \pm 73.6 \mathrm{ab}$ & $480 \pm 31.5 \mathrm{abc}$ \\
$\mathrm{G}$ & $0.63 \pm 0.16 \mathrm{~b}$ & $1.39 \pm 0.22 \mathrm{bc}$ & $357 \pm 40.1 \mathrm{~d}$ & $369 \pm 48.3 \mathrm{bcd}$ \\
$\mathrm{HS}$ & $0.82 \pm 0.11 \mathrm{~b}$ & $1.63 \pm 0.21 \mathrm{abc}$ & $533 \pm 77.1 \mathrm{bcd}$ & $365 \pm 23.4 \mathrm{~cd}$ \\
$\mathrm{~B}+\mathrm{G}$ & $0.81 \pm 0.13 \mathrm{~b}$ & $1.77 \pm 0.22 \mathrm{ab}$ & $569 \pm 61.6 \mathrm{bc}$ & $511 \pm 44.1 \mathrm{ab}$ \\
$\mathrm{B}+$ HS & $0.65 \pm 0.15 \mathrm{~b}$ & $1.95 \pm 0.10 \mathrm{ab}$ & $388 \pm 51.2 \mathrm{~cd}$ & $515 \pm 58.7 \mathrm{a}$ \\
$\mathrm{HS}+\mathrm{G}$ & $0.60 \pm 0.05 \mathrm{~b}$ & $1.51 \pm 0.24 \mathrm{bc}$ & $625 \pm 45.0 \mathrm{~b}$ & $319 \pm 56.9 \mathrm{~d}$ \\
$\mathrm{~B}+$ HS + G & $2.46 \pm 0.27 \mathrm{a}$ & $2.15 \pm 0.14 \mathrm{a}$ & $854 \pm 75.6 \mathrm{a}$ & $452 \pm 44.7 \mathrm{abcd}$ \\
$(p$-value $)$ & $<0.0001$ & 0.0124 & 0.0001 & 0.0148 \\
\hline
\end{tabular}

Values are means of four replicates. Standard error: \pm . Values followed by the same letter in the columns do not differ significantly by Duncan's test $(p \leq 0.05) . \quad \mathrm{C}=$ control; $\mathrm{B}=$ biochar; $\mathrm{G}=$ gypsum; HS = humic substances; $\mathrm{B}+\mathrm{G}=$ biochar + gypsum; $\mathrm{B}+\mathrm{HS}=$ biochar + humic substances; HS + G = humic substances + gypsum; $\mathrm{B}+\mathrm{HS}+\mathrm{G}=$ biochar + humic substances + gypsum.

Table 2. Influence of chemical and organic amendments on the physiological parameters of quinoa genotypes grown in saline-sodic soil.

\begin{tabular}{|c|c|c|c|c|}
\hline \multirow[t]{2}{*}{ Treatments } & \multicolumn{2}{|c|}{$\begin{array}{l}\text { Chlorophyll Index } \\
\text { SPAD (Soil Plant Analysis } \\
\text { Development) }\end{array}$} & \multicolumn{2}{|c|}{$\begin{array}{l}\text { Stomatal Conductance } \\
\left(\mathrm{mmol} \mathrm{m}^{-2} \mathrm{~s}^{-1}\right)\end{array}$} \\
\hline & AZ-51 & AZ-103 & AZ-51 & AZ-103 \\
\hline $\mathrm{C}$ & $47.49 \pm 1.20 \mathrm{a}$ & $46.85 \pm 1.57 \mathrm{~d}$ & $106 \pm 10.64 c$ & $100 \pm 4.93 \mathrm{~d}$ \\
\hline B & $53.40 \pm 2.17 \mathrm{a}$ & $61.70 \pm 1.24 \mathrm{ab}$ & $116 \pm 4.51 \mathrm{bc}$ & $136 \pm 7.04 b c$ \\
\hline G & $54.37 \pm 1.67 \mathrm{a}$ & $62.13 \pm 1.04 \mathrm{ab}$ & $137 \pm 6.98 \mathrm{ab}$ & $147 \pm 9.23 b c$ \\
\hline HS & $50.33 \pm 1.49 \mathrm{a}$ & $54.98 \pm 0.85 c$ & $138 \pm 7.75 \mathrm{ab}$ & $133 \pm 7.74 c$ \\
\hline$B+G$ & $55.80 \pm 2.43 \mathrm{a}$ & $61.03 \pm 0.66 b$ & $137 \pm 8.63 \mathrm{ab}$ & $137 \pm 8.09 b c$ \\
\hline $\mathrm{B}+\mathrm{HS}$ & $52.31 \pm 1.23 \mathrm{a}$ & $59.65 \pm 1.37 \mathrm{~b}$ & $132 \pm 5.12 \mathrm{ab}$ & $127 \pm 8.66 c$ \\
\hline $\mathrm{HS}+\mathrm{G}$ & $52.13 \pm 1.40 \mathrm{a}$ & $65.27 \pm 2.45 \mathrm{a}$ & $122 \pm 9.38 \mathrm{abc}$ & $160 \pm 5.92 \mathrm{ab}$ \\
\hline $\mathrm{B}+\mathrm{HS}+\mathrm{G}$ & $50.13 \pm 2.80 \mathrm{a}$ & $55.48 \pm 0.37 c$ & $145 \pm 8.39 \mathrm{a}$ & $181 \pm 8.78 \mathrm{a}$ \\
\hline ( $p$-value) & 0.1028 & $<0.0001$ & 0.0412 & 0.0001 \\
\hline
\end{tabular}

Values are means of four replicates. Standard error: \pm . Values followed by the same letter in the columns do not differ significantly by Duncan's test $(p \leq 0.05)$. $\mathrm{C}=$ control; $\mathrm{B}=$ biochar; $\mathrm{G}=$ gypsum; $\mathrm{HS}=$ humic substances; $\mathrm{B}+\mathrm{G}=$ biochar + gypsum; $\mathrm{B}+\mathrm{HS}=$ biochar + humic substances; $\mathrm{HS}+\mathrm{G}=$ humic substances + gypsum; $\mathrm{B}+\mathrm{HS}+\mathrm{G}=$ biochar + humic substances + gypsum. 


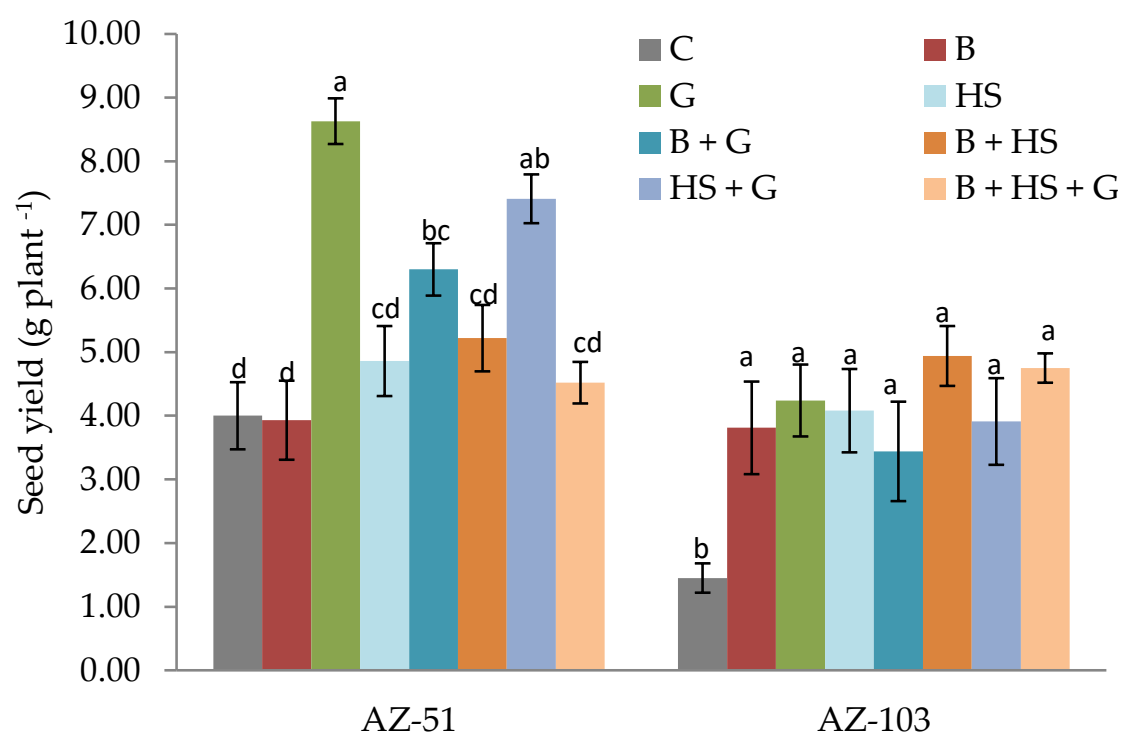

Figure 1. Seed yield (g plant ${ }^{-1}$ ) of quinoa genotypes grown in saline-sodic soil in response to chemical and organic amendments. Values are means of four replicates. Error bars represent the standard error. Significance: (AZ-51 $p<0.0001)$; (AZ-103 $p=0.0009$ ). Values with the same letter are not significantly different according to Duncan's test $(p \leq 0.05) . \mathrm{C}=$ control; $\mathrm{B}=$ biochar; $\mathrm{G}$ = gypsum; $\mathrm{HS}=$ humic substances; $\mathrm{B}+\mathrm{G}$ = biochar + gypsum; $\mathrm{B}+\mathrm{HS}$ = biochar + humic substances; $\mathrm{HS}+\mathrm{G}=$ humic substances + gypsum; $\mathrm{B}+\mathrm{HS}+\mathrm{G}=$ biochar + humic substances + gypsum.

\subsection{Polyphenols and Protein Content in Quinoa Seeds}

Total polyphenol content $(\mathrm{GAE})$ did not show significant differences ( $p$ value $=0.2239)$ between treatments in AZ-51 genotype compared to the control. Nevertheless, significant differences were found in AZ-103, with a $28 \%$ decrease in GAE concentration in the B + HS + G treatment compared to the control (Table 3).

Protein content in seeds of AZ-51 genotype recorded significant increases of $45,34,29$, and $26 \%$ in HS; HS + G; B + HS; and B + HS + G treatments, respectively. This parameter recorded an increase of $23 \%$ in the biochar treatment in seeds of AZ-103 genotype compared to the control (Table 3).

Table 3. Contents of polyphenols (Gallic Acid Equivalent, GAE) and protein in quinoa seeds.

\begin{tabular}{ccccc}
\hline \multirow{2}{*}{ Treatments } & \multicolumn{2}{c}{ Polyphenols (GAE mg g } & & \multicolumn{2}{c}{ Protein (\%) } \\
\cline { 2 - 5 } & AZ-51 & AZ-103 & AZ-51 & AZ-103 \\
\hline C & $1.02 \pm 0.08 \mathrm{a}$ & $1.2 \pm 0.07 \mathrm{ab}$ & $9.3 \pm 0.72 \mathrm{~d}$ & $11.4 \pm 0.27 \mathrm{~b}$ \\
B & $0.75 \pm 0.06 \mathrm{a}$ & $1.05 \pm 0.09 \mathrm{bc}$ & $11.1 \pm 0.61 \mathrm{bcd}$ & $14.0 \pm 0.53 \mathrm{a}$ \\
G & $0.91 \pm 0.06 \mathrm{a}$ & $1.22 \pm 0.14 \mathrm{ab}$ & $10.4 \pm 0.82 \mathrm{~cd}$ & $10.8 \pm 0.19 \mathrm{~b}$ \\
HS & $0.71 \pm 0.03 \mathrm{a}$ & $1.02 \pm 0.09 \mathrm{bc}$ & $13.5 \pm 0.26 \mathrm{a}$ & $10.3 \pm 0.48 \mathrm{~b}$ \\
B + G & $0.81 \pm 0.16 \mathrm{a}$ & $1.38 \pm 0.11 \mathrm{a}$ & $10.7 \pm 0.76 \mathrm{bcd}$ & $11.9 \pm 0.37 \mathrm{~b}$ \\
B + HS & $0.87 \pm 0.12 \mathrm{a}$ & $1.21 \pm 0.11 \mathrm{ab}$ & $12.0 \pm 0.10 \mathrm{abc}$ & $11.3 \pm 0.70 \mathrm{~b}$ \\
HS + G & $0.78 \pm 0.15 \mathrm{a}$ & $1.12 \pm 0.09 \mathrm{abc}$ & $12.5 \pm 0.44 \mathrm{ab}$ & $11.8 \pm 0.92 \mathrm{~b}$ \\
B+ HS + G & $0.73 \pm 0.05 \mathrm{a}$ & $0.87 \pm 0.08 \mathrm{c}$ & $11.8 \pm 0.50 \mathrm{abc}$ & $11.3 \pm 0.37 \mathrm{~b}$ \\
$(p$-value) & 0.2239 & 0.0137 & 0.0018 & 0.0029 \\
\hline
\end{tabular}

Values are means of four replicates. Standard error: \pm . Values followed by the same letter in the columns do not differ significantly by Duncan's test $(p \leq 0.05) . \quad \mathrm{C}=$ control; $\mathrm{B}=$ biochar; $\mathrm{G}=$ gypsum; HS = humic substances; $\mathrm{B}+\mathrm{G}=$ biochar + gypsum; $\mathrm{B}+\mathrm{HS}=$ biochar + humic substances; $\mathrm{HS}+\mathrm{G}=$ humic substances + gypsum; $\mathrm{B}+\mathrm{HS}+\mathrm{G}=$ biochar + humic substances + gypsum. 


\subsection{Effects of Amendments on the Chemical and Biological Properties of Saline-Sodic Soils}

Electrical conductivity of the saturation paste extract decreased significantly with the application of most of the soil amendments compared to the control. Amendment applications resulted in a significant reduction in salinity (ECe) that ranged from 33 to $46 \%$ (in AZ-51 genotype), except in the biochar treatment. In AZ-103 genotype, ECe was also significantly lower in all treatments, with decreases that ranged from 52 to $68 \%$ when compared to the control (Table 4).

Sodium adsorption ratio (SAR) decreased significantly in all amended soils. The maximum decreases were obtained with gypsum (a 10.9-fold decrease on average) for individual applications, and with $B+G$ in case of combined treatments (a 15.2-fold decrease on average) compared to the control (Table 4).

All treated soils recorded significantly lower soil ESP values. The largest reduction in ESP for individual applications was observed with the $G$ treatment, which exhibited an 11-fold reduction in soil ESP compared to the control. In case of combined applications, the maximum decreases in ESP were recorded in $B+G ; B+H S$; and $B+H S+G$ treatments, with reductions that ranged from 9- to 13-fold compared to the control treatment (Table 4).

Exchangeable $\mathrm{Ca}^{2+}$ concentrations were 40, 27, and 23\% higher in G; B + HS + G; and HS + G treatments, respectively, in AZ-51 genotype. The same treatments showed a similar trend in AZ-103 genotype. In addition, B + HS; B + G; and B treatments also resulted in significant increases in exchangeable $\mathrm{Ca}^{2+}$ concentrations that ranged from 54 to $14 \%$ (Table 5).

Soil Exchangeable $\mathrm{Mg}^{2+}$ was significantly lower in both AZ-51 and AZ-103 with the B + G treatment (20 and $24 \%$, respectively) compared to the control (Table 5).

Soil Exchangeable $\mathrm{Na}^{+}$concentrations were significantly reduced in all treated soils (Table 5). In AZ-51genotype, exchangeable $\mathrm{Na}^{+}$concentrations were $85 \%$ to $93 \%$ lower than the control for combined applications; whereas values were $87 \%$ to $91 \%$ lower for individual applications. A similar trend was observed in AZ-103 as exchangeable $\mathrm{Na}^{+}$concentrations reduced from 82 to $92 \%$ and 81 to $89 \%$ in combined and individual applications, respectively, compared to the control.

Regarding biological soil analysis, soil and respiration microbial biomass presented significantly increases in most of the treatments. All amended soils recorded significant increases in soil microbial biomass compared to the control (Figure 2). Thus, the highest values for microbial biomass in both genotypes were obtained with following treatments: B + HS + G; HS + G; B; and B + HS (ranging from 12.2 to $14.1 \mu \mathrm{g} \mathrm{FDA} \mathrm{g}^{-1}$ soil).

Soil microbial respiration also had significant increases in most treatments (Figure 3). In AZ-51 genotype, the highest values in soil microbial respiration were observed in B + HS + G; B + G; and B, with values 130,88 , and $85 \%$ higher, respectively, than the control. In AZ-103 genotype, all treated soils recorded significant increases with respect to untreated soils, with values 285,227 , and $211 \%$ higher than the control for B + HS + G; B; and HS + G treatments, respectively. 
Table 4. Chemical soil properties measured after the application of amendments.

\begin{tabular}{ccccccc}
\hline \multirow{2}{*}{ Treatments } & \multicolumn{2}{c}{ ECe $\left(\mathbf{d S ~ m}^{\mathbf{- 1}}\right.$ ) } & \multicolumn{2}{c}{ SAR (meq $\left.\mathbf{1}^{\mathbf{- 1}}\right)^{\mathbf{1 / 2}}$} & \multicolumn{2}{c}{ ESP (\%) } \\
\cline { 2 - 7 } & AZ-51 & AZ-103 & AZ-51 & AZ-103 & AZ-51 & AZ-103 \\
\hline C & $9.1 \pm 0.3 \mathrm{a}$ & $13.2 \pm 0.4 \mathrm{a}$ & $9.7 \pm 0.7 \mathrm{a}$ & $10.0 \pm 0.3 \mathrm{a}$ & $15.0 \pm 1.3 \mathrm{a}$ & $21.5 \pm 1.2 \mathrm{a}$ \\
B & $8.1 \pm 0.7 \mathrm{a}$ & $5.5 \pm 0.8 \mathrm{bc}$ & $1.4 \pm 0.2 \mathrm{~b}$ & $2.2 \pm 0.4 \mathrm{~b}$ & $2.2 \pm 0.4 \mathrm{bc}$ & $4.5 \pm 0.5 \mathrm{~b}$ \\
G & $5.7 \pm 0.4 \mathrm{~b}$ & $6.1 \pm 0.7 \mathrm{~b}$ & $0.9 \pm 0.0 \mathrm{~cd}$ & $0.9 \pm 0.1 \mathrm{de}$ & $1.3 \pm 0.1 \mathrm{~d}$ & $2.1 \pm 0.2 \mathrm{def}$ \\
HS & $5.3 \pm 0.4 \mathrm{~b}$ & $4.5 \pm 0.3 \mathrm{bc}$ & $1.3 \pm 0.1 \mathrm{bc}$ & $1.4 \pm 0.2 \mathrm{cde}$ & $2.2 \pm 0.1 \mathrm{~b}$ & $3.7 \pm 0.4 \mathrm{bc}$ \\
B + G & $6.1 \pm 0.8 \mathrm{~b}$ & $6.3 \pm 0.6 \mathrm{~b}$ & $0.6 \pm 0.0 \mathrm{~d}$ & $0.7 \pm 0.1 \mathrm{e}$ & $1.2 \pm 0.1 \mathrm{~d}$ & $1.7 \pm 0.2 \mathrm{f}$ \\
B + HS & $6.1 \pm 0.8 \mathrm{~b}$ & $4.2 \pm 0.4 \mathrm{c}$ & $0.8 \pm 0.1 \mathrm{~d}$ & $1.2 \pm 0.1 \mathrm{de}$ & $1.4 \pm 0.2 \mathrm{~cd}$ & $2.0 \pm 0.3 \mathrm{ef}$ \\
HS + G & $4.9 \pm 0.2 \mathrm{~b}$ & $4.7 \pm 0.5 \mathrm{bc}$ & $1.2 \pm 0.2 \mathrm{bc}$ & $1.9 \pm 0.2 \mathrm{bc}$ & $2.1 \pm 0.1 \mathrm{~b}$ & $4.0 \pm 0.5 \mathrm{bcd}$ \\
B+ HS + G & $5.3 \pm 0.4 \mathrm{~b}$ & $4.6 \pm 0.6 \mathrm{bc}$ & $0.7 \pm 0.0 \mathrm{~d}$ & $1.36 \pm 0.3 \mathrm{~cd}$ & $1.2 \pm 0.0 \mathrm{bcd}$ & $2.4 \pm 0.5 \mathrm{cde}$ \\
$(p$-value) & 0.0001 & $<0.0001$ & $<0.0001$ & $<0.0001$ & $<0.0001$ & $<0.0001$ \\
\hline
\end{tabular}

Values are means of four replicates. Standard error: \pm . Values followed by the same letter in the columns do not differ significantly by Duncan's test $(p<0.05) . \mathrm{C}=$ control; $\mathrm{B}=$ biochar; $\mathrm{G}=$ gypsum; $\mathrm{HS}=$ humic substances; $\mathrm{B}+\mathrm{G}=$ biochar + gypsum; $\mathrm{B}+\mathrm{HS}=$ biochar + humic substances; $\mathrm{HS}+\mathrm{G}=$ humic substances + gypsum; $\mathrm{B}+\mathrm{HS}+\mathrm{G}=$ biochar + humic substances + gypsum.

Table 5. Soil exchangeable $\mathrm{Ca}^{2+}, \mathrm{Mg}^{2+}$, and $\mathrm{Na}^{+}$concentrations after the application of amendments.

\begin{tabular}{|c|c|c|c|c|c|c|}
\hline \multirow{2}{*}{ Treatments } & \multicolumn{2}{|c|}{$\mathrm{Ca}^{2+}\left(\mathrm{cmol} \mathrm{kg}^{-1}\right)$} & \multicolumn{2}{|c|}{$\mathrm{Mg}^{2+}\left(\mathrm{cmol} \mathrm{kg}^{-1}\right)$} & \multicolumn{2}{|c|}{$\mathrm{Na}^{+}\left(\mathrm{cmol} \mathrm{kg}^{-1}\right)$} \\
\hline & AZ-51 & AZ-103 & AZ-51 & AZ-103 & AZ-51 & AZ-103 \\
\hline C & $52 \pm 0.9 \mathrm{~d}$ & $50 \pm 0.9 \mathrm{~d}$ & $8.4 \pm 0.8 \mathrm{ab}$ & $11.1 \pm 0.7 \mathrm{ab}$ & $10.9 \pm 1.2 \mathrm{a}$ & $16.8 \pm 1.6 \mathrm{a}$ \\
\hline B & $57 \pm 4.2 \mathrm{bcd}$ & $57 \pm 1.7 \mathrm{c}$ & $7.7 \pm 0.2 \mathrm{bc}$ & $10.5 \pm 0.6 \mathrm{ab}$ & $1.40 \pm 0.2 b c$ & $3.20 \pm 0.4 b$ \\
\hline G & $73 \pm 2.3 a$ & $76 \pm 1.1 \mathrm{a}$ & $8.0 \pm 0.3 \mathrm{ab}$ & $9.5 \pm 0.4 b c$ & $1.03 \pm 0.0 \mathrm{bc}$ & $1.87 \pm 0.1 \mathrm{cde}$ \\
\hline HS & $54 \pm 2.1 \mathrm{~cd}$ & $54 \pm 0.6 \mathrm{~cd}$ & $8.4 \pm 0.2 \mathrm{ab}$ & $11.1 \pm 0.7 \mathrm{ab}$ & $1.38 \pm 0.1 \mathrm{bc}$ & $2.50 \pm 0.3 \mathrm{bcd}$ \\
\hline$B+G$ & $59 \pm 1.9 \mathrm{bcd}$ & $67 \pm 2.3 \mathrm{~b}$ & $6.7 \pm 0.2 c$ & $8.4 \pm 0.5 c$ & $0.80 \pm 0.1 \mathrm{c}$ & $1.29 \pm 0.2 \mathrm{e}$ \\
\hline $\mathrm{B}+\mathrm{HS}$ & $57 \pm 2.9 \mathrm{bcd}$ & $77 \pm 0.6 \mathrm{a}$ & $8.4 \pm 0.2 \mathrm{ab}$ & $10.2 \pm 0.3 \mathrm{ab}$ & $0.95 \pm 0.1 \mathrm{c}$ & $1.77 \pm 0.3 \mathrm{de}$ \\
\hline $\mathrm{HS}+\mathrm{G}$ & $64 \pm 1.8 \mathrm{bc}$ & $70 \pm 1.2 \mathrm{~b}$ & $8.9 \pm 0.2 \mathrm{a}$ & $11.7 \pm 0.6 \mathrm{a}$ & $1.59 \pm 0.1 \mathrm{~b}$ & $3.07 \pm 0.5 b c$ \\
\hline $\mathrm{B}+\mathrm{HS}+\mathrm{G}$ & $66 \pm 5.7 \mathrm{ab}$ & $65 \pm 0.3 b$ & $8.2 \pm 0.5 \mathrm{ab}$ & $10.9 \pm 0.7 \mathrm{ab}$ & $0.89 \pm 0.1 \mathrm{c}$ & $1.94 \pm 0.5$ cde \\
\hline ( $p$-value) & 0.0011 & $<0.0001$ & 0.0192 & 0.0127 & $<0.0001$ & $<0.0001$ \\
\hline
\end{tabular}

Values are means of four replicates. Standard error: \pm . Values followed by the same letter in the columns do not differ significantly by Duncan's test $(p \leq 0.05)$. $\mathrm{C}=$ control; $\mathrm{B}=$ biochar; $\mathrm{G}=$ gypsum; HS = humic substances; $\mathrm{B}+\mathrm{G}=$ biochar + gypsum; $\mathrm{B}+\mathrm{HS}=$ biochar + humic substances; $\mathrm{HS}+\mathrm{G}=$ humic substances + gypsum; $\mathrm{B}+\mathrm{HS}+\mathrm{G}=$ biochar + humic substances + gypsum.

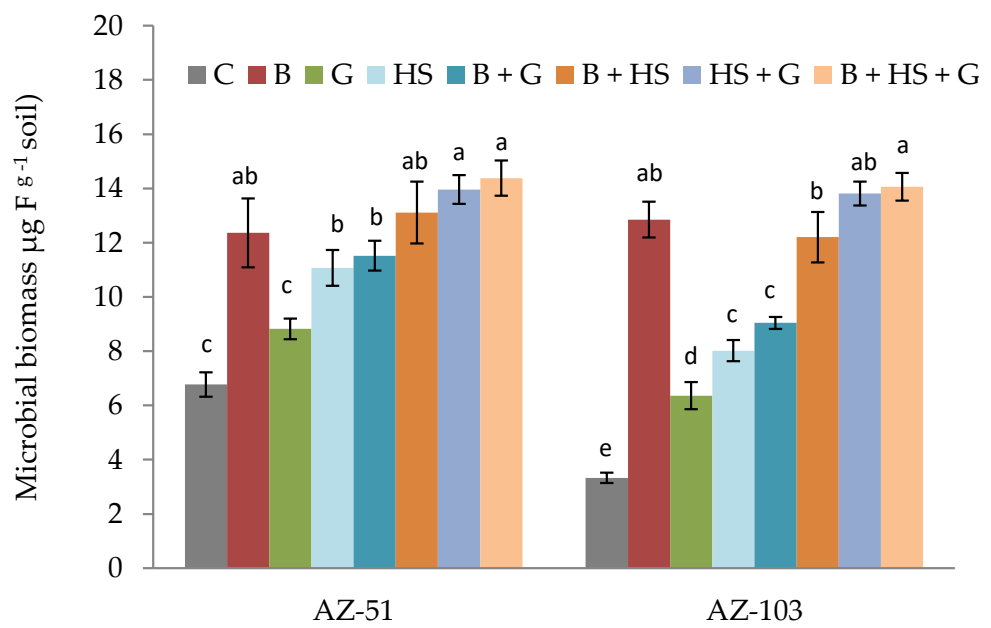

Figure 2. Microbial biomass (Fluorescein diacetate hydrolyzing activity $\mu g$ FDA $^{-1}$ soil) in saline-sodic soil after the application of chemical and organic amendments. Values are means of four replicates. Error bars represent the standard error. Significance: (AZ-51 $p<0.0001)$; (AZ-103 $p<0.0001$ ). Values with the same letter are not significantly different according to Duncan's test $(p \leq 0.05)$. $\mathrm{C}=$ control; $\mathrm{B}=$ biochar; $\mathrm{G}=$ gypsum; $\mathrm{HS}=$ humic substances; $\mathrm{B}+\mathrm{G}=$ biochar + gypsum; $\mathrm{B}+\mathrm{HS}$ = biochar + humic substances; HS + G = humic substances + gypsum; B + HS + G = biochar + humic substances + gypsum. 


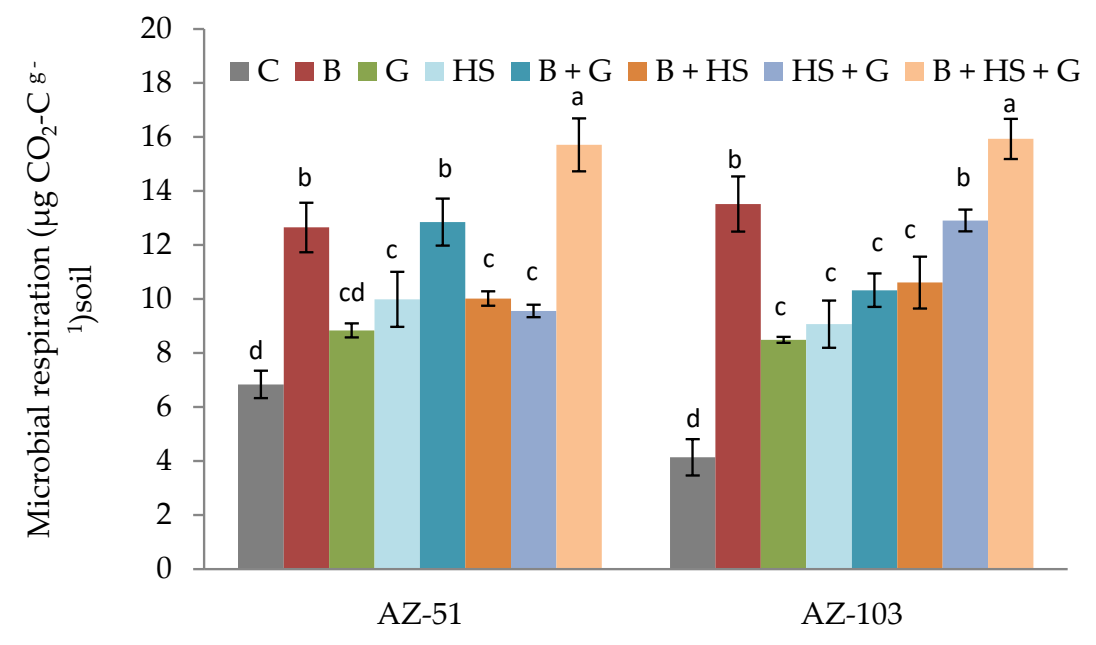

Figure 3. Microbial respiration $\left(\mu \mathrm{g} \mathrm{CO} \mathrm{CO}_{2}-\mathrm{Cg}^{-1}\right)$ in saline-sodic soil after the application of chemical and organic amendments. Values are means of four replicates. Error bars represent the standard error. Significance: (AZ-51 $p<0.0001)$; (AZ-103 $p<0.0001)$. Values with the same letter are not significantly different according to Duncan's test $(p \leq 0.05)$. $\mathrm{C}=$ control; $\mathrm{B}=$ biochar; $\mathrm{G}=$ gypsum; HS = humic substances; $B+\mathrm{G}=$ biochar + gypsum; $\mathrm{B}+\mathrm{HS}=$ biochar + humic substances; $\mathrm{HS}+\mathrm{G}=$ humic substances + gypsum; B + HS + G = biochar + humic substances + gypsum.

\section{Discussion}

Soil salinity greatly reduces plant growth by osmotic stress, hormonal imbalance, nutrient deficiencies, and specific ion toxicity [36]. The results obtained in the present study indicate that applications of biochar, humic substances, and gypsum could mitigate part of these negative effects on quinoa plants. Agricultural productivity in saline-sodic soils can be recovered through the application of combined amendments due to the restorative effect of these amendments on the physical, chemical and biological conditions of these soils, in this way the quinoa could be cultivated in soils characterized by excess salt problems. In fact, the combined application of $B+H S+G$ resulted in a significant increase in root biomass in AZ-51 genotype, but the highest increases were observed in AZ-103 genotype with the same treatment (Table 1). This may be explained because the combination of HS and $B$ induces exudation of organic compounds produced by the plant microbiota, which positively affects root development $[37,38]$. Additionally, the fact that B can exclude salts from root system can also account for this situation [39]. Combinations of organic amendments and G significantly improved soil properties, which in turn supported prolific root growth of plants [40]. Similar results were also found by Kammann et al. [37], who observed enhanced root growth (fine root mass) in quinoa plants after B applications. According to Akhtar et al. [39], B positively affects plant root growth under saline conditions, due to its high adsorption capacity, which might lead to reduce $\mathrm{Na}^{+}$uptake or enhanced $\mathrm{Na}^{+}$exclusion or both from roots. These observations are in agreement with the results obtained in this study as significant decreases were obtained in leaf $\mathrm{Na}^{+}$concentrations in amended soils (data not shown). Humic substances improve soil microbial activity because of their auxin-like hormone activity, which stimulates root morphology [38].

In terms of SPAD chlorophyll index, the results show significant increases in all treated soils in AZ-103 genotype (Table 2). When submitted to saline conditions, chlorophyll content generally decreases in salt-sensitive plants, whereas it increases in salt-tolerant species [41]. This is consistent with our results since the unamended treatment showed a significantly lower SPAD index value. This indicates that amendments have a positive effect as their applications result in increased chlorophyll content in plants under salinity stress. This is in agreement with Ramzani et al. [10], who confirmed that chlorophyll content in quinoa plants grown under saline conditions was positively affected by B and compost applications compared to the control treatment. Nevertheless, AZ-51 
genotype showed no significant response in terms of SPAD values (Table 2). In fact, this might be related to genetic diversity between genotypes, possibly due to leaf internal mechanisms in AZ-51 plants. This may allow a better adaptation to salinity conditions, maintaining an adequate photosynthetic activity. Based on this, responses were not so evident to amendment applications. Some genotypes present salt adapting mechanisms with physiological responses that result in phenotypic plasticity of leaves to abiotic stress. Therefore, leaf morphological traits, such as associated photosynthetic function, vary depending on the environment and its genetic plasticity [42].

Most of amendment applications (individual and combined) tested in this study showed statistically significant increases in stomatal conductance respect to untreated soil (Table 2). These results agree with those reported by Akhtar el al. [43], who described that B incorporation into the soil increased both stomatal aperture and density, which implies reduced stress in wheat plants. This can be also attributed to B as it can enhance soil water-holding capacity, which should help mitigate salt-induced osmotic stress and ion toxicity to plants due to dilution effect. Moreover, HS increased photosynthesis and respiration rates in plants due to the presence of phytohormones, such as auxin and gibberellins; these are directly involved in various biochemical mechanisms inside plant cells and enzymatic activities involved in carbohydrate metabolism [44]. Conversely, stomatal conductance decreased in unamended soils in this study due to stomatal closure. To endure osmotic constraint, salt-tolerant plants are more restrictive with water loss via transpiration by a sensitive stomatal closure mechanism; this leads to a restricted availability of $\mathrm{CO}_{2}$ for carboxylation reaction, which favors the formation of Reactive Oxygen Species (ROS) [45].

Salt stress has also been identified as a major factor limiting crop productivity in saline-sodic soils [36]. The results show that quinoa seed yield significantly increased in G; and HS + G (in AZ-51 genotype). Similarly, all treated soils in AZ-103 genotype improved seed yield significantly (Figure 1). Similar results have been reported by Lashari et al. [46], who evaluated wheat growth in salt-stressed soils and found increases in grain yields after B and compost applications. This could be attributed to multiple effects by amendment applications on quinoa plants grown in salt-affected soil, such as root development, hormonal and metabolic activity leading to higher seed yield. In fact, HS increased root growth through indole acetic acid (IAA), resulting in enhanced root surface area, and thus enabling plant access to nutrients and boosting yield [47]. In addition, Turan et al. [48] indicated that increases in seed yield may be explained because HS increase the production of adenosine triphosphate (ATP) within plant cells and thus increase permeability, resulting in rises of nutrient transport to sites of metabolic demand. Another study reported that, B application supplied nutrients to plants, triggered changes in soil redox conditions, enhanced microbial biomass, and increased water holding capacity, increasing plant tolerance to saline stress and also plant dry yield [22]. Moreover, Spokas et al. [49] suggested that $\mathrm{B}$ amendments incorporated into the soil are an ethylene source that stimulates plant growth and yield, and Agegnehu et al. [50] conducted a study that evaluated the effects of B on soil quality and maize growth. These authors indicated that B increased growth and grain yield due to greater pore spaces, leading to a higher nutrient supply to plants. Likewise, Mahmood et al. [51], reported significant improvement on wheat plant growth and yield $(25 \%$ to $43 \%)$ in saline-sodic soils reclaimed with $G$, which has been attributed to increases in $\mathrm{Ca}^{+2}$ build-up, elimination of $\mathrm{Na}^{+}$toxicity and nutritional balance in plants. Although G and HS improved productivity of AZ-51 genotype, B did not significantly increased genotype yield, probably because the contribution of labile or leachable $\mathrm{C}$ and some nutrient fractions were very transient [22], considering that this genotype exhibited a late maturation compared to AZ-103 genotype ( 25 days after). The B and HS rate is another factor that could have limited the effect on this variable [52], since this genotype had a higher average yield of $45 \%$ (greater export of nutrients) than the genotype with early maturation.

Polyphenol content was evaluated as a functional quality indicator of quinoa seeds whose role is to reduce the damages caused by ROS (Table 3). Most of the treatments did not affect the GAE content significantly. Both genotypes presented a certain degree of tolerance to the salinity level of the soil under study. This could have a negative influence on the induction to protective mechanisms, such as 
polyphenol synthesis. Quinoa plants might use enzymatic antioxidant and non-enzymatic antioxidant compounds as polyphenols, which have a strong ability to scavenge ROS [53]. This was supported by Ruiz et al. [6], who reported that seeds harvested from R49 and VR quinoa genotypes, grown in saline soils, showed higher GAE content compared to control treatments.

The highest significant protein content was obtained in quinoa seeds grown in HS and B treatments in AZ-51 and AZ-103 genotypes, respectively (Table 3). These findings agree with results of previous experiments in which organic amendment applications into a saline soil improved the nutritional quality in quinoa seeds [10]. A similar response was observed in wheat grains grown in calcareous soils [54]. This increased protein content of quinoa seed could be explained by the role of organic amendments for overall improvement in soil health and delivery of essential nutrients to plants [55]. In addition, reduction in salt toxicity to plants through the adsorption of $\mathrm{Na}^{+}$on large $\mathrm{B}$ surface areas in the soil might be another possible mechanism for the increase in protein content of quinoa seeds $[22,56]$.

Soil salinity also generates osmotic effects in plants and often causes physiological drought if it exceeds a critical threshold in crops [57]. Amendment applications improved chemical properties of soils (decreases soil salinity), influenced by effective salt leaching from soil profile. In our experiment, most of amended soils (except B treatment in AZ-51 genotype) showed significant decreases in soil ECe compared to control soils (Table 4), suggesting that these amendments have a strong efficiency in reducing soil ECe. Similar results were also reported by Tejada et al. [16] and Gupta et al. [17], who reported that soil EC was significantly lower when organic amendments and $G$ were applied to reclaim salt-affected soils compared to the control.

Application of chemical and organic amendments increases the concentration of $\mathrm{Ca}^{2+}$ and promotes the displacement of adsorbed $\mathrm{Na}^{+}$. We found that SAR and ESP values reduced significantly in all amended soils. These results agree with a study of Chaganti et al. Ref. [58], who found that organic amendments (biochar, biosolids, green waste compost) improved soil hydraulic conductivity, thus facilitating salt leaching of saline-sodic soil and allowing for a significant decrease in soil ESP and SAR. Moreover, Mahmoodabadi et al. [13] reported that organic amendments decreased soil SAR due to a reduction in $\mathrm{Na}^{+}$solution concentrations and enhanced $\mathrm{Ca}^{2+}$ supply. Relative changes in soil exchangeable $\mathrm{Na}^{+}$are dependent on chemical reactions in the soil matrix. Chemical reactions take place between soil solution and exchange phases due to changes in chemical concentrations of monovalent and divalent cations [23]. In this regard, Nan et al. [57] applied G and HS in a sodic soil and observed improved structural stability and a reduction of ESP from soil colloids. In this sense, salts could be leached down to deeper layers. Moreover, Vijayasatya et al. [23] reported that B incorporation to saline-sodic soil reduced ESP by $83 \%$ when compared to the control after leaching. Likewise, Aktar et al. $[39,43]$ attributed the reduction of soil salinity with B to: (1) the adsorption/retention of salts, such as $\mathrm{Na}^{+}$on biochar surfaces, or salt physical entrapment in $\mathrm{B}$ fine pores, and (2) biochar-induced reduction in upward movement of saline water.

Significantly higher concentrations of soil exchangeable cation $\left(\mathrm{Ca}^{2+}\right)$ were observed after the application of combined amendments and $G$ treatments (Table 5). These results suggest that $\mathrm{HS}, \mathrm{B}$, and $\mathrm{G}$ have a synergistic effect to carry more $\mathrm{Ca}^{2+}$ into the soil solution. HS, B, and G increased $\mathrm{Ca}^{2+}$ content in saline-sodic soil, which improved exchange of sodium from soil exchange sites $[14,15,57,58]$. Nevertheless, the individual application of (B) and (HS) did not significantly increased soil exchangeable cation $\left(\mathrm{Ca}^{2+}\right)$ or this increase was very low (e.g. HS in AZ-103 genotype; Table 5). This could be probably attributed to the chemical composition of Biochar $(0.8 \% \mathrm{Ca})$.

Some differences in the final concentrations of bivalent cations (e.g. $\mathrm{Ca}, \mathrm{Mg}$ ) arise from the chemical composition of applied organic amendments [13]. In the present study, soil exchangeable $\mathrm{Mg}^{2+}$ did not increase significantly after amendment applications (Table 5). These results agree with the findings of Chaganti et al. [23], who applied composts and B in a saline-sodic soil and found that exchangeable $\mathrm{Mg}^{2+}$ concentrations did not differ statistically respect to untreated soil. 
It is widely acknowledged that divalent cation $\mathrm{Ca}^{2+}$ can replace adsorbed $\mathrm{Na}^{+}$in soil colloids, causing flocculation of colloids and improving soil structure [59]. This is a key point for a successful reclamation of saline-sodic soil. We found that soil exchangeable $\mathrm{Na}^{+}$concentrations significantly decreased in all treated soils respect to untreated soils (Table 5). These results are in agreement with previously reported findings $[13,17,57,58]$. Nevertheless, individual applications of B and HS did not increase $\mathrm{Ca}^{2+}$ concentrations in soil but they significantly decreased $\mathrm{Na}^{+}$concentrations; these effects might be explained by HS and B applications to saline soils, resulting in reductions of sodium salt concentrations, which is not correlated with salt leaching, yet it may be correlated with improving root growth and accumulation of $\mathrm{Na}^{+}$in the root surface area (biochar) $[22,60]$.

Several processes and materials able to alter soil $\mathrm{C}$ content can affect biomass and activity of microbial communities. B and HS can improve the growth of microorganisms in salt-affected soils in many ways, including: increasing water retention and supply to microbes, releasing soil nutrients for microbes, stimulating root exudation of dissolved organic carbon and nitrogen, which are needed for microbial metabolism. We found that soil microbial biomass (FDA) significantly increased with most of the treatments in both quinoa genotypes, except with the G treatment in AZ-51 genotype, which was similar to the control (Figure 2). These results are consistent with our hypothesis that $B$ and HS enhance soil microbial activity. Zheng et al. [24] noticed that B (peanut Shell $350{ }^{\circ} \mathrm{C}$ ) induced a microbial response in the rhizosphere. Moreover, Bhaduri et al. [61] also reported that $\mathrm{B}$ application (peanut Shell $300{ }^{\circ} \mathrm{C}$, in $5 \%$ dose) on saline soil influenced microbial growth and $\mathrm{C}$ use efficiency led to increases in soil microbial biomass. According to Pukalchik et al. [62], addition of HS stimulated heterotrophic microorganisms in the soil, and consequently restored soil microbial respiration in multi-contaminated soils. Our results indicate that there is a synergistic effect between B + HS + G that leads to enhancements in soil microbial biomass and respiration (Figures 1 and 3 ). The positive effect of $B$ on microbial biomass can be explained because the internal pore system of $B$ particles may protect microorganisms. Microbial sorption to B may occur via flocculation, adsorption on surfaces, and entrapment in a matrix [22]. According to Whitman et al. [63], microbial responses to B addition could be attributed to modified substrate availability (e.g. $\mathrm{C}$ and $\mathrm{N}$ ), due to labile $\mathrm{C}$ input from biochar and soil chemical properties such as salt stress (e.g. ECe, ESP, Table 3). On the other hand, microorganisms can be stimulated by a HS addition through enriched surfactant-like interaction. Lipczynska-Kochani et al. [64] suggested that HS have direct effects on enzymes and oxidative stress defense. In addition, HS should be considered as a significant carbon source for soil bacteria [64]. Control soils showed values of microbial biomass FDA (enzymatic activities) significantly lower than those observed in other treated soils (Figure 3), which indicates that biochemical quality is negatively affected by saline-sodic soils. This may be due to a salting-out effect, which involves a decrease in enzyme solubility through dehydration (osmotic effect), thus altering enzyme catalytic sites [16,65].

Consequently, the application of combined amendments may be considered as a promising technique to enhance the biological quality of saline-sodic soils. However, the role of biochar in soil biological processes represents a frontier in soil science research, with many unexplained phenomena that require further research [22].

\section{Conclusions}

The combination of biochar, humic substances and gypsum $(B+H S+G)$ resulted in the highest increases in root biomass in both AZ-51 and AZ-103 quinoa genotypes. Stomatal conductance, SPAD index, and seed yield increased significantly in all treated soil as compared to the control in AZ-103 genotype, while increases were also observed in the most of the treatments of AZ-51 genotype. Seed yield doubled in AZ-51 after applications of G; and HS + G; whereas similar increases were obtained in all amended soils in AZ-103. Seed quality (protein content) was positively affected by $\mathrm{B}$ and HS amendment applications. These results suggest that each genotype responded differentially to amendment applications. On the other hand, soil sodicity and salinity (ESP; ECe) were significantly reduced with all individual and combined amendments. The most effective treatments in reducing 
sodicity levels through increases in soil exchangeable $\mathrm{Ca}^{2+}$ concentrations were: $\mathrm{G}$; $\mathrm{B}+\mathrm{G}$; $\mathrm{B}+\mathrm{HS}$; and $\mathrm{B}+\mathrm{HS}+\mathrm{G}$. Moreover, soil microbial biomass was mostly stimulated with the B + HS + G combined treatment. In this sense, the use of combined amendments improved the chemical and biological properties of the soil, reducing the negative effects of saline-sodic soil on the growth of quinoa genotypes. This paper provided the first results regarding the performance of AZ-51 and AZ-103 quinoa genotypes when grown in saline-sodic soil and their responses to different amendments. Field trials are required to fully understand the behavior of the most effective treatments identified in this experiment $(B+H S+G ; B+G$; and $B+H S)$.

Author Contributions: M.A. and M.S. (Mauricio Schoebitz) conceived designed and performed the experiments. M.A., A.Z.-S., M.S. (Marco Sandoval), C.M., and M.S. (Mauricio Schoebitz) analyzed the data and contributed to the writing of the paper. All authors read, discussed, and approved the final manuscript.

Acknowledgments: This research was supported by Fondecyt Initiation Project $\mathrm{N}^{\circ} 11170254$.

Conflicts of Interest: The authors declare no conflict of interest.

\section{References}

1. Young, J.; Udeigwe, T.K.; Weindorf, D.C.; Kandakji, T.; Gautam, P.; Mahmoud, M.A. Evaluating management-induced soil salinization in golf courses in semi-arid landscapes. Solid Earth 2015, 6, 393-402. [CrossRef]

2. Yu, J.; Wang, Z.; Meixner, F.X.; Yang, F.; Wu, H.; Chen, X. Biogeochemical characterizations and reclamation strategies of saline sodic soil in northeastern China. CLEAN-Soil, Air, Water 2010, 38, 1010-1016. [CrossRef]

3. Wong, V.N.; Dalal, R.C.; Greene, R.S. Salinity and sodicity effects on respiration and microbial biomass of soil. Biol. Fertil. Soils 2008, 44, 943-953. [CrossRef]

4. Parida, A.K.; Das, A.B. Salt tolerance and salinity effects on plants: a review. Ecotox. Environ. Safe. 2005, 60, 324-349. [CrossRef] [PubMed]

5. Petropoulos, S.A.; Levizou, E.; Ntatsi, G.; Fernandes, Â.; Petrotos, K.; Akoumianakis, K.; Barros, L.; Ferreira, I.C. Salinity effect on nutritional value, chemical composition and bioactive compounds content of Cichorium spinosum L. Food Chem. 2017, 214, 129-136. [CrossRef] [PubMed]

6. Ruiz, K.B.; Aloisi, I.; Del Duca, S.; Canelo, V.; Torrigiani, P.; Silva, H.; Biondi, S. Salares versus coastal ecotypes of quinoa: salinity responses in Chilean landraces from contrasting habitats. Plant Physiol. Bioch. 2016, 101, 1-13. [CrossRef] [PubMed]

7. Razzaghi, F.; Jacobsen, S.-E.; Jensen, C.R.; Andersen, M.N. Ionic and photosynthetic homeostasis in quinoa challenged by salinity and drought-mechanisms of tolerance. Funct. Plant Biol. 2015, 42, 136-148. [CrossRef]

8. Nowak, V.; Du, J.; Charrondière, U.R. Assessment of the nutritional composition of quinoa (Chenopodium quinoa Willd.). Food Chem. 2016, 193, 47-54. [CrossRef] [PubMed]

9. Hariadi, Y.; Marandon, K.; Tian, Y.; Jacobsen, S.-E.; Shabala, S. Ionic and osmotic relations in quinoa (Chenopodium quinoa Willd.) plants grown at various salinity levels. J. Exp. Bot. 2010, 62, 185-193. [CrossRef] [PubMed]

10. Ramzani, P.M.A.; Shan, L.; Anjum, S.; Ronggui, H.; Iqbal, M.; Virk, Z.A.; Kausar, S. Improved quinoa growth, physiological response, and seed nutritional quality in three soils having different stresses by the application of acidified biochar and compost. Plant Physiol. Bioch. 2017, 116, 127-138. [CrossRef] [PubMed]

11. Yazdanpanah, N.; Pazira, E.; Neshat, A.; Mahmoodabadi, M.; Sinobas, L.R. Reclamation of calcareous saline sodic soil with different amendments (II): Impact on nitrogen, phosphorous and potassium redistribution and on microbial respiration. Agr. Water Manage. 2013, 120, 39-45. [CrossRef]

12. Agriculture Organization. The State of Food Insecurity in the World 2014; FAO: Rome, Italy, 2014.

13. Mahmoodabadi, M.; Yazdanpanah, N.; Sinobas, L.R.; Pazira, E.; Neshat, A. Reclamation of calcareous saline sodic soil with different amendments (I): Redistribution of soluble cations within the soil profile. Agr. Water Manage. 2013, 120, 30-38. [CrossRef]

14. Yaduvanshi, N.P.S.; Sharma, D.R. Tillage and residual organic manures/chemical amendment effects on soil organic matter and yield of wheat under sodic water irrigation. Soil Till. Res. 2008, 98, 11-16. [CrossRef] 
15. Yaduvanshi, N.P. Nutrient management for sustained crop productivity in sodic soils: a review. In Soil Salinity Management in Agriculture: Technological Advances and Applications; Gupta, S.K., Goyal, M.R., Eds.; CRC Press: Boca Raton, FL, USA, 2017; pp. 365-394.

16. Tejada, M.; Garcia, C.; Gonzalez, J.L.; Hernandez, M.T. Use of organic amendment as a strategy for saline soil remediation: influence on the physical, chemical and biological properties of soil. Soil Biolo. Bioch. 2006, 38, 1413-1421. [CrossRef]

17. Gupta, M.; Srivastava, P.K.; NIRANJAN, A.; TEWARI, S.K. Use of a bioaugmented organic soil amendment in combination with gypsum for Withania somnifera growth on sodic soil. Pedosphere 2016, 26, 299-309. [CrossRef]

18. Clemente, R.; Bernal, M.P. Fractionation of heavy metals and distribution of organic carbon in two contaminated soils amended with humic acids. Chemosphere 2006, 64, 1264-1273. [CrossRef] [PubMed]

19. Ciarkowska, K. Effect of fertilization on the structure of upland grassland soil. Pol. J. Environ. Stud. 2010, 19, 693-697.

20. Ciarkowska, K.; Solek-Podwika, K.; Filipek-Mazur, B.; Tabak, M. Comparative effects of lignite-derived humic acids and FYM on soil properties and vegetable yield. Geoderma 2017, 303, 85-92. [CrossRef]

21. Lehmann, J.; Joseph, S. Biochar for environmental management: An introduction. In Biochar for Environmental Management: Science, Technology and Implementation, 2nd ed.; Lehmann, J., Joseph, S., Eds.; Earths can: London, UK, 2015; pp. 1-15.

22. Lehmann, J.; Rillig, M.C.; Thies, J.; Masiello, C.A.; Hockaday, W.C.; Crowley, D. Biochar effects on soil biota-a review. Soil Biolo. Bioch. 2011, 43, 1812-1836. [CrossRef]

23. Chaganti, V.N.; Crohn, D.M. Evaluating the relative contribution of physiochemical and biological factors in ameliorating a saline-sodic soil amended with composts and biochar and leached with reclaimed water. Geoderma 2015, 259, 45-55. [CrossRef]

24. Zheng, H.; Wang, X.; Chen, L.; Wang, Z.; Xia, Y.; Zhang, Y.; Wang, H.; Luo, X.; Xing, B. Enhanced growth of halophyte plants in biochar-amended coastal soil: roles of nutrient availability and rhizosphere microbial modulation. Plant Cell Environ. 2018, 41, 517-532. [CrossRef] [PubMed]

25. Soil Survey Staff. Soil Taxonomy: A Basic System of Soil Classification for Making and Interpreting Soil Surveys, 2nd ed.; US Government Printing Office: Washington, DC, USA, 1999.

26. Cade-Idepe. Consultores en Ingeniería. 2004. Cuenca del Río Huasco: diagnóstico y clasificación de agua según objetivos de calidad [en línea]. Ministerio de Obras Públicas, Chile. Available online: http://portal.mma.gob.cl/diagnostico-y-clasificacion-de-cursos-y-cuerpos-de-aguasegun-objetivos-de-calidad/ (accessed on 15 January 2018).

27. Gatica, S. Estudio de Caso; diagnóstico de los suelos y de las aguas para regadío del sector de Huasco Bajo, Región de Atacama, Chile. Tesis Pregrado, Universidad de Concepción, Chillán, 2013.

28. Muñoz, C.; Quilodrán, C.; Navia, R. Evaluation of biochar-plant extracts complexes on soil nitrogen dynamics. J. Biobased Mater. Bio. 2014, 8, 377-385. [CrossRef]

29. Sayegh, A.H.; Khan, N.A.; Khan, P.; Ryan, J. Factors Affecting Gypsum and Cation Exchange Capacity Determinations in Gypsiferous SOILS1. Soil Sci. 1978, 125, 294-300. [CrossRef]

30. Kim, H.-S.; Kim, K.-R.; Yang, J.E.; Ok, Y.S.; Owens, G.; Nehls, T.; Wessolek, G.; Kim, K.-H. Effect of biochar on reclaimed tidal land soil properties and maize (Zea mays L.) response. Chemosphere 2016, 142, 153-159. [CrossRef] [PubMed]

31. Quezada, C.; Sandoval, M.; Stolpe, N.; Olmos, D. Uso de enmiendas orgánicas y químicas para la remediación de suelos inundados por el tsunami de 2010 en la zona de Tomé, Chile. Chilean J. Agric. Anim. Sci. 2016, 32, $13-22$.

32. Lachman, J.; Dudjak, J.; Orsák, M.; Pivec, V. Effect of accelerated ageing on the content and composition of polyphenolic complex of wheat (Triticum aestivum L.) grains. Plant Soil Environ. 2003, 49, 1-7. [CrossRef]

33. Sadzawka, M.A.R.; Carrasco, A.M.R.; Demanet, F.R.; Flores, P.H.; Grez, Z.R.; Mora, G.M.L.; Neaman, A. Métodos de Análisis Recomendados Para los Suelos de Chile. In Proceedings of the INIA Serie Actas No 34, Santiago, Chile, 2006; Revisión 2006. Available online: http:/ / www.cofes.org.ar/descargas/relas/4_ jornada/Manual_chilenos_suelos_2006.pdf (accessed on 7 August 2018).

34. Alef, K. Methods in Applied Soil Microbiology and Biochemistry; Alef, K., Nannipieri, P., Eds.; Academic Press: London, UK, 1995; pp. 232-233. 
35. Sadzawka, M.A.R.; Carrasco, A.M.R.; Demanet, F.R.; Flores, P.H.; Grez, Z.R.; Mora, G.M.L.; Neaman, A. Métodos de Análisis de Tejidos Vegetales. In Proceedings of the INIA Serie Actas No 40, Santiago, Chile, 2007; Available online: http:/ / www.cofes.org.ar/descargas/relas/4_jornada/Manual_chilenos_tejido_vegetal. pdf (accessed on 7 August 2018).

36. Qadir, M.; Ghafoor, A.; Murtaza, G. Amelioration strategies for saline soils: a review. Land Degrad. Dev. 2000, 11, 501-521. [CrossRef]

37. Kammann, C.I.; Linsel, S.; Gößling, J.W.; Koyro, H.-W. Influence of biochar on drought tolerance of Chenopodium quinoa Willd and on soil-plant relations. Plant Soil 2011, 345, 195-210. [CrossRef]

38. Arjumend, T.; Abbasi, M.K.; Rafique, E. Effects of lignite-derived humic acid on some selected soil properties, growth and nutrient uptake of wheat (Triticum aestivum L.) grown under greenhouse conditions. Pakistan J. Bot. 2015, 47, 2231-2238.

39. Akhtar, S.S.; Andersen, M.N.; Liu, F. Biochar mitigates salinity stress in potato. J. Agron. Crop Sci. 2015, 201, 368-378. [CrossRef]

40. Gill, J.S.; Sale, P.W.G.; Peries, R.R.; Tang, C. Changes in soil physical properties and crop root growth in dense sodic subsoil following incorporation of organic amendments. Field Crop. Res. 2009, 114, 137-146. [CrossRef]

41. Khan, M.A.; Shirazi, M.U.; Khan, M.A.; Mujtaba, S.M.; Islam, E.; Mumtaz, S.; Shereen, A.; Ansari, R.U.; Ashraf, M.Y. Role of proline, K/Na ratio and chlorophyll content in salt tolerance of wheat (Triticum aestivum L.). Pak. J. Bot. 2009, 41, 633-638.

42. González, J.A.; Ponessa, G.I.; Buedo, S.; Mercado, M.I.; Prado, F.E. Asimilación fotosintética máxima en variedades de quinoa (Chenopodium quinoa) de diferentes orígenes geográficos y su relación con la morfología foliar. Lilloa 2014, 51. [CrossRef]

43. Akhtar, S.S.; Andersen, M.N.; Liu, F. Residual effects of biochar on improving growth, physiology and yield of wheat under salt stress. Agr. Water Manage. 2015, 158, 61-68. [CrossRef]

44. Nardi, S.; Pizzeghello, D.; Muscolo, A.; Vianello, A. Physiological effects of humic substances on higher plants. Soil Biolo. Bioch. 2002, 34, 1527-1536. [CrossRef]

45. Benzarti, M.; Rejeb, K.B.; Debez, A.; Messedi, D.; Abdelly, C. Photosynthetic activity and leaf antioxidative responses of Atriplex portulacoides subjected to extreme salinity. Acta Physiol. Plant. 2012, 34, 1679-1688. [CrossRef]

46. Lashari, M.S.; Liu, Y.; Li, L.; Pan, W.; Fu, J.; Pan, G.; Zheng, J.; Zheng, J.; Zhang, X.; Yu, X. Effects of amendment of biochar-manure compost in conjunction with pyroligneous solution on soil quality and wheat yield of a salt-stressed cropland from Central China Great Plain. Field Crop. Res. 2013, 144, 113-118. [CrossRef]

47. Trivedi, P.; Singh, K.; Pankaj, U.; Verma, S.K.; Verma, R.K.; Patra, D.D. Effect of organic amendments and microbial application on sodic soil properties and growth of an aromatic crop. Ecol. Eng. 2017, 102, 127-136. [CrossRef]

48. Turan, M.A.; Baris, B.A.; Katkat, A.V.; Celik, H. The effects of soil-applied humic substances to the dry weight and mineral nutrient uptake of maize plants under soil-salinity conditions. Not. Bot. Horti. Agro. 2011, 39, 171. [CrossRef]

49. Spokas, K.A.; Baker, J.M.; Reicosky, D.C. Ethylene: potential key for biochar amendment impacts. Plant Soil 2010, 333, 443-452. [CrossRef]

50. Agegnehu, G.; Bird, M.I.; Nelson, P.N.; Bass, A.M. The ameliorating effects of biochar and compost on soil quality and plant growth on a Ferralsol. Soil Res. 2015, 53, 1-12. [CrossRef]

51. Mahmood, I.A.; Salim, M.; Ali, A.; Arshadullah, M.; Zaman, B.; Mir, A. Impact of calcium sulphate and calcium carbide on nitrogen use efficiency of wheat in normal and saline sodic soils. Soil Environ. 2009, 28, 29-37.

52. Hartz, T.K.; Bottoms, T.G. Humic substances generally ineffective in improving vegetable crop nutrient uptake or productivity. HortScience 2010, 45, 906-910.

53. Srivastava, A.K.; Srivastava, S.; Lokhande, V.H.; D’Souza, S.F.; Suprasanna, P. Salt stress reveals differential antioxidant and energetics responses in glycophyte (Brassica juncea L.) and halophyte (Sesuvium portulacastrum L.). Front. Env. Sci. 2015, 3, 19. [CrossRef]

54. Ramzani, P.M.A.; Khalid, M.; Naveed, M.; Ahmad, R.; Shahid, M. Iron biofortification of wheat grains through integrated use of organic and chemical fertilizers in $\mathrm{pH}$ affected calcareous soil. Plant Phy. Bioch. 2016, 104, 284-293. [CrossRef] [PubMed] 
55. Shahbaz, A.K.; Lewińska, K.; Iqbal, J.; Ali, Q.; Iqbal, M.; Abbas, F.; Tauqeer, H.M.; Ramzani, P.M.A. Improvement in productivity, nutritional quality, and antioxidative defense mechanisms of sunflower (Helianthus annuus L.) and maize (Zea mays L.) in nickel contaminated soil amended with different biochar and zeolite ratios. J. Environ. Manage. 2018, 218, 256-270. [CrossRef] [PubMed]

56. Dahlawi, S.; Naeem, A.; Rengel, Z.; Naidu, R. Biochar application for the remediation of salt-affected soils: Challenges and opportunities. Sci. Total Environ. 2018, 625, 320-335.

57. Nan, J.; Chen, X.; Wang, X.; Lashari, M.S.; Wang, Y.; Guo, Z.; Du, Z. Effects of applying flue gas desulfurization gypsum and humic acid on soil physicochemical properties and rapeseed yield of a saline-sodic cropland in the eastern coastal area of China. J. Soil. Sediment. 2016, 16, 38-50. [CrossRef]

58. Chaganti, V.N.; Crohn, D.M.; Šimŭnek, J. Leaching and reclamation of a biochar and compost amended saline-sodic soil with moderate SAR reclaimed water. Agr. Water Manage. 2015, 158, 255-265. [CrossRef]

59. Jalali, M. Effect of sodium and magnesium on kinetics of potassium release in some calcareous soils of western Iran. Geoderma 2008, 145, 207-215. [CrossRef]

60. Çimrin, K.M.; Türkmen, Ö.; Turan, M.; Tuncer, B. Phosphorus and humic acid application alleviate salinity stress of pepper seedling. Afr.J. Biotechnol. 2010, 9, 5845-5851.

61. Bhaduri, D.; Saha, A.; Desai, D.; Meena, H.N. Restoration of carbon and microbial activity in salt-induced soil by application of peanut shell biochar during short-term incubation study. Chemosphere 2016, 148, 86-98. [CrossRef] [PubMed]

62. Pukalchik, M.; Mercl, F.; Panova, M.; Břendová, K.; Terekhova, V.A.; Tlustoš, P. The improvement of multi-contaminated sandy loam soil chemical and biological properties by the biochar, wood ash, and humic substances amendments. Environ. Pollut. 2017, 229, 516-524. [CrossRef] [PubMed]

63. Whitman, T.; Pepe-Ranney, C.; Enders, A.; Koechli, C.; Campbell, A.; Buckley, D.H.; Lehmann, J. Dynamics of microbial community composition and soil organic carbon mineralization in soil following addition of pyrogenic and fresh organic matter. ISME J. 2016, 10, 2918. [CrossRef] [PubMed]

64. Lipczynska-Kochany, E. Humic substances, their microbial interactions and effects on biological transformations of organic pollutants in water and soil: A review. Chemosphere 2018, 202, 423-429. [CrossRef] [PubMed]

65. Tripathi, S.; Kumari, S.; Chakraborty, A.; Gupta, A.; Chakrabarti, K.; Bandyapadhyay, B.K. Microbial biomass and its activities in salt-affected coastal soils. Biol. Fertil Soils 2006, 42, 273-277. [CrossRef] 